\title{
Assessment of agro-ecological service crop managements combined with organic fertilisation strategies in organic melon crop
}

\author{
Mariangela Diacono, ${ }^{1}$ Corrado Ciaccia, ${ }^{1}$ Stefano Canali, ${ }^{1}$ Angelo Fiore, ${ }^{1}$ \\ Francesco Montemurro ${ }^{1,2}$ \\ ${ }^{1}$ Consiglio per la ricerca in agricoltura e l'analisi dell'economia agraria - Research Centre for Agriculture and \\ Environment (CREA-AA), Bari and Roma; ${ }^{2}$ Consiglio per la ricerca in agricoltura e l'analisi dell'economia \\ agraria - Research Centre for Vegetable and Ornamental Crops (CREA-OF), Monsampolo del Tronto (AP), Italy
}

\begin{abstract}
In organic horticultural systems, cover crops could provide several ecological services, therefore, they can be defined agroecological service crops (ASCs). The objective of this two-year research was to study the suitability on melon production of different ASC termination strategies, in combination with organic fertilisers application. In a split-block design, the main-plot was the ASC management, comparing: i) green manure, in which the vetch was chopped and plowed into the soil; and ii) roller-crimper (RC), in which the vetch was flattened by a roller-crimper; with iii) fallow control, without vetch. The subplot consisted of offfarm organic inputs: i) commercial humified fertiliser; ii) anaerobic digestate fertiliser; iii) composted municipal solid wastes; which were compared to iv) unfertilised control (N0). At vetch termination, above soil biomass and nitrogen $(\mathrm{N})$ content were determined. At harvesting, crop yield performance and quality, $\mathrm{N}$ status and $\mathrm{N}$ efficiency were investigated. Also, main soil characteristics were assessed at the end of the trial. Among the ASC managements, the slightly reduced yield in the RC plots particularly in combination with N0 might have been the result of less N supplied by the vetch during the melon cycle. Anyway, no negative effects were observed for yield quality. The use of the RC showed a great potential in enhancing soil fertility. Our study suggests the suitability in organic farming of properly matching management of ASC and fertilisation strategies on melon crop.
\end{abstract}

Correspondence: Mariangela Diacono, Consiglio per la ricerca in agricoltura e l'analisi dell'economia agraria - Research Centre for Agriculture and Environment (CREA-AA), via Celso Ulpiani 5, 70125 Bari, Italy. Tel.: +39.080.5475052 - Fax: +39.080.5475023.

E-mail: mariangela.diacono@crea.gov.it

Key words Cucumis melo; cover crops; green manure; organic fertilisers; roller crimper.

Received for publication: 1 March 2017.

Revision received: 26 June 2017.

Accepted for publication: 5 July 2017.

(C) Copyright M. Diacono et al., 2018

Licensee PAGEPress, Italy

Italian Journal of Agronomy 2018; 13:951

doi:10.4081/ija.2018.951

This article is distributed under the terms of the Creative Commons Attribution Noncommercial License (by-nc 4.0) which permits any noncommercial use, distribution, and reproduction in any medium, provided the original author(s) and source are credited.

\section{Introduction}

Diversified crop rotations and the use of cover crops have been recently rediscovered by farmers and used in orchards and horticultural systems worldwide (Campiglia et al., 2011; Lesueur Jannoyer et al., 2011; Wezel et al., 2014). In rotational systems, cover crops can provide fundamental ecological services, thus enhancing agro-ecosystem sustainability (Kremen and Miles, 2012), promoting in-field biodiversity (Fageria et al., 2005) and reducing weed (Bàrberi, 2002; Hayden et al., 2012), disease and arthropod pests occurrence (Masiunas, 1998; Patkowska et al., 2013). Moreover, cover crops can contribute to improve system energy use efficiency (Gomiero et al, 2008), influence greenhouse gases emission (Sanz-Cobena et al., 2014), increase soil organic C storage (Mazzoncini et al., 2011), reduce nutrient losses from the agro-ecosystem (Kristensen and Thorup-Kristensen, 2004) and then positively influence soil fertility (Thorup-Kristensen et al., 2012). The most recent scientific literature defined cover crops as agro-ecological service crops (ASC), due to their ability to provide this wide range of services (Canali et al., 2015). Among ASC, the legume crops are mostly incorporated into the soil as green manure, exploiting their ability to fix, accumulate and supply nitrogen $(\mathrm{N})$, therefore, reducing or replacing off-farm $\mathrm{N}$ fertilisers (Smukler et al., 2012). In particular, the use of common vetch (Vicia sativa L.) as ASC may improve soil fertility and increase the yield of the subsequent crop in rotation, because of its rapidly decomposable biomass containing huge $\mathrm{N}$ amounts and relatively low carbon to nitrogen ratio (Blanco-Canqui et al., 2012). In order to allow timely production by the main crops, the cropping cycle of ASC is ended in advance of their physiological maturity by chemical (herbicides) and/or mechanical methods (Carrera et al., 2004). In particular, in organic farming, ASC termination is achieved by mechanical chopping and/or plowing, field disking, mowing or crushing with a roller-crimper (Kornecki et al., 2009; Wortman et al., 2012). Despite the termination by roller-crimper represents the most recent development in ASC management, it has not been utilised fully (Lu et al., 2000). The roller damages the plants by lodging them, keeping the above ground part of the plant attached to its root system, thus reducing the contact with soil microorganisms than in mowing. Therefore, it could determine a lower decomposition rate than other termination techniques (i.e. chopping and ploughing ASC into the soil), reducing $\mathrm{N}$ release, but exerting a long-lasting weed control. Difficulties may occur in matching the crop growth stage for ASC termination using the roller-crimper, due to differing $\mathrm{ASC} /$ cash crop phenologies (Delate et al., 2012; Teasdale et al., 2012). Moreover, legume ASC may not be able to provide sufficient $\mathrm{N}$ synchronised with the subsequent cash crop demand, which is particularly relevant in organic vegetable cropping systems, characterised by the high nutrient 
demand and low $\mathrm{N}$ utilisation efficiency (Canali et al., 2010). To reduce $\mathrm{N}$ deficiency, supplemental soil fertility-building strategies, based on the use of off- or in-farm fertilisers, may be necessary (Muramoto et al., 2011), while avoiding excessive amounts of $\mathrm{N}$ fertiliser that could determine groundwater contamination by nitrates and negative effects on production and quality (Bhella and Wilcox, 1986; Cabello et al., 2009). In such a context, combining different ASC managements and organic fertilisation strategies can ensure crop performance and sustainability of the system (Mazzoncini et al., 2011; Rizk, 2012). Organic materials generally presenting notable contents of organic matter and nutrients, such as by-products of farming and agro-industries, animal manures, food processing wastes and municipal biosolids could be used to sustain soil fertility (Diacono and Montemurro, 2011). Their use in agriculture can contribute to closing the natural ecological cycle even if it is necessary to preliminarily adopt controlled biodegradation processes, able to minimise potentially negative environmental impact of the organic materials.

Despite the great potential of combined practices, farmers concerns about the implications of the ASC (e.g. reduced available soil moisture for the subsequent cash crop) still limit the full adoption of them. This is mainly due to lack of knowledge and dissemination about the best agronomic approaches, particularly in organically managed vegetable cropping systems in the Mediterranean environment. Therefore, in order to investigate the effectiveness of the combination of ASC termination strategies with different organic fertilisers and amendments to improve melon crop performance and soil fertility, the main objectives of this study were: i) identifying the strategies with the highest cash crop yield potential; ii) evaluating the treatments combination with the most significant effect on the soil fertility.

\section{Materials and methods}

\section{Study site and weather conditions}

The research was carried out during two years (2011-2012 and 2012-2013, hereafter reported as Year 1 and Year 2, respectively) at Metaponto (MT) in southern Italy (lat. $40^{\circ} 24^{\prime} \mathrm{N}$; long. $16^{\circ} 48^{\prime}$ $\mathrm{E}$ and $8 \mathrm{~m}$ a.s.1.), in a field located at the research farm 'Campo 7' (CREA-AA-AZ-MET), of the Consiglio per la ricerca in agricoltura e l'analisi dell'economia agraria - Research Centre for Agriculture and Environment (CREA-AA).

The soil, classified as a Typic Epiaquert (Soil Survey Staff, 1999), has a clay loam texture and contains $1.0 \mathrm{~g} \mathrm{~kg}^{-1}$ of $\mathrm{N}$ and $19.0 \mathrm{~g} \mathrm{~kg}^{-1}$ of organic matter, $759 \mathrm{mg} \mathrm{kg}^{-1}$ of exchangeable potassium (K), $31.1 \mathrm{mg} \mathrm{kg}^{-1}$ of Olsen available phosphorus (P), and has a $\mathrm{pH}$ value of 8.4. Clay and silt contents are 60 and $36 \%$, respectively, and electrical conductivity $(1: 10(\mathrm{w} / \mathrm{v})$ water-soluble extraction) is $0.48 \mathrm{dS} \mathrm{m}^{-1}$ at $0-30 \mathrm{~cm}$ depth, increasing with depth. Cation exchange capacity is $27.1 \mathrm{meq} 100 \mathrm{~g}^{-1}$ of dry soil, with 15.5 and 8.6 meq100 $\mathrm{g}^{-1}$ of calcium and magnesium, respectively. Soil water content is 34.5 and $20.1 \%$ (as a percentage of soil-dry weight $)$ at field capacity $(-0.03 \mathrm{MPa})$ and permanent wilting point $(-1.5 \mathrm{MPa})$, respectively. The average soil bulk density is $1350 \mathrm{~kg}$ $\mathrm{m}^{-3}$. The climate is classified as accentuated thermomediterranean according to the UNESCO-FAO classification (UNESCO-FAO, $1963)$, with mean monthly temperatures of $8.8^{\circ} \mathrm{C}$ in the winter and $24.4^{\circ} \mathrm{C}$ in the summer. The site is characterised by winter temperatures which can fall below $0^{\circ} \mathrm{C}$, and summer temperatures which can rise above $40^{\circ} \mathrm{C}$. Rainfall (average $490 \mathrm{~mm}^{-1}{ }^{-1}$ ) is unevenly distributed during the year and concentrated mainly in the winter months. The annual potential evaporation rate is high with a mean annual pan evaporation rate of $1549 \mathrm{~mm}$. Mean monthly temperatures and the rainfall during the field trial, compared to the average long-term values (30 years) are reported in Figure 1.

Before the experiment, wheat crop was cultivated. Then, in 2011 a two-year rotation melon-cauliflower started, with the same experimental design and crop management. During the rotation, each plot received the same treatment to assess the residual effects of organic fertilisation.

\section{Experimental design and crop management}

The experimental design was a split-block with two factors and three replicates (blocks). The main-plot factor was the ASC management, and the following different treatments were compared in strips randomised over each block: i) green manure (GM), in which the vetch biomass was chopped and incorporated into the soil (about $20 \mathrm{~cm}$ depth) by plowing; $v s$ ii) roller-crimper (RC), in which the vetch biomass was flattened by a roller-crimper to create a mulch layer; which were compared to iii) fallow (FA), in which common vetch (Vicia sativa L. Buza) was not planted, and the soil was tilled before melon transplanting, according to common local practices. The roller crimper utilised was endowed of disks and chisels, operating in line to simultaneously flatten the ASC and to obtain a $0.2-0.3 \mathrm{~m}$ deep and few centimeters wide transplanting furrow without disturbing the mulch layer, which remains in place covering the soil surface. Additional information about the features of the in line tillage roller crimper (ILRC) system are available in Canali et al. (2013). The subplot factor consisted of the following off-farm organic fertilisers and amendments which were arranged in strips orthogonal to the vetch residues management systems across each main block, to make easier management operations: i) a commercial humified fertiliser, based on dried animal manure (CHF) (Fertilhumus, DELTA s.a.s); ii) anaerobic digestate fertiliser (AD), based on wine distillery waste (derived from distillation and extraction of tartaric acid from grape skins); iii) composted municipal solid wastes (MSW), obtained in the closed and monitored processing plant of the Progeva company $\mathrm{Srl}$ ); these three organic fertilisers were compared to iv) an unfertilised control (N0). More information about both the AD and MSW production processes are reported in Montemurro et al. (2013). All the fertilisers are allowed in organic farming in accordance to the European Regulation (Commission Regulation $N^{\circ} 889 / 2008$ of 5 September 2008 for EU Council Regulation $\mathrm{N}^{\circ}$ 834/2007). The fertilisers

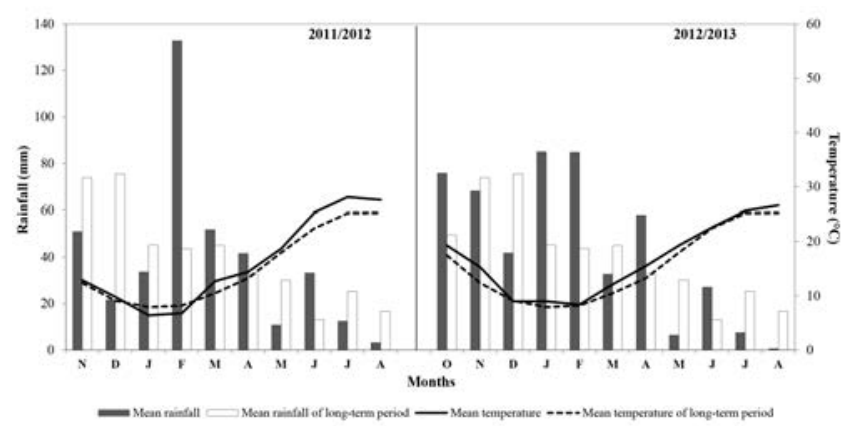

Figure 1. Weather conditions (rainfall and mean temperatures) recorded during the melon growing seasons of 2011-2012 and 2012-2013. These values are compared to the rainfall and mean temperatures of 1981-2010. 
were applied to supply $100 \mathrm{~kg} \mathrm{~N}^{-1}$ in $\mathrm{GM}$ and $\mathrm{RC}$ compared to $200 \mathrm{~kg} \mathrm{~N} \mathrm{ha}^{-1}$ in FA, taking into account that ASC will supply at least $50 \%$ of the $\mathrm{N}$ in the first two treatments (Sullivan, 1998), even if in different moments. In fact, in the RC treatment, the aboveground residues of the flattened mulch were incorporated into the soil after the melon crop, whereas in GM the vetch supplied the additional $\mathrm{N}$ during green manuring within the cash crop cycle. The $\mathrm{N}$ supplied by vetch to the melon crop was also determined considering that the estimated aboveground $\mathrm{N}$ content of vetch is $90 \%$, the roots containing $10 \% \mathrm{~N}$ (Shipley et al., 1992). Therefore, RC was supposed to readily supply only a small part of the $\mathrm{N}$, contained in the vetch roots $(10 \%$ of $\mathrm{N}$ uptake of $\mathrm{ASC}$, as assumption).

The GM plots were weeded through a rotary tillage between rows, RC through 2 hoeings (about 15 and 25 days after sowing) during the cropping cycle, considering the rapid cover by melon crop that generally improves competition with weeds, and FA through 1 rotary tillage (i.e., by using standard agronomic practices on organic farming in the area).

Vetch was sown at the rate of $80 \mathrm{~kg} \mathrm{ha}^{-1}$ in the GM and RC treatments, on 16 ${ }^{\text {th }}$ November 2011 and 22 ${ }^{\text {nd }}$ October 2012 for experimental years 1 and 2, respectively, and it was terminated at the first legume stage, when plants produced the first pods at the end of flowering. This stage occurred on $15^{\text {th }}$ and $17^{\text {th }}$ April in 2012 (year 1) and 2013 (year 2), respectively. The organic fertilisers (the same in both trial years) were applied to soil 20 days before transplanting melon seedlings [Cucumis melo L. var. Emerson F1 (ISI 54201)], which occurred on $9^{\text {rd }}$ and $6^{\text {th }}$ May 2012 and 2013, respectively, at $140 \times 100 \mathrm{~cm}$ spacing. Melon crop was cultivated on 3 plots of $235.2 \mathrm{~m}^{2}(19.6 \times 12 \mathrm{~m})$ at $2 \mathrm{~m}$ distance between them, on 36 sub-plots each of about $20 \mathrm{~m}^{2}(4.9 \times 4 \mathrm{~m})$.

All treatments were irrigated with the same volume of water calculated to reach $100 \%$ of available soil water for a soil depth of $0-40 \mathrm{~cm}$ at each irrigation. Following this procedure, in both years, about $3500 \mathrm{~m}^{3} \mathrm{ha}^{-1}$ of water were distributed. The ETm was calculated on the basis of evaporation rate from Class A pan (Doorenbos and Pruitt, 1977) and the crop coefficient was applied according to FAO-56 paper (Allen et al., 1998). The evaporation rate from Class A pan and meteorological data were recorded on hourly basis by an automated data-logger located in the experimental area. Irrigation water was supplied by localised irrigation method. The watering was applied when cumulated crop evapotranspiration value reached $19.44 \mathrm{~mm}$ (from transplanting to blooming) and $38.88 \mathrm{~mm}$ (from full bloom to fruit ripening).

\section{Data collection and measurements}

Chemical characteristics of AD and MSW were determined on five samples taken every year randomly from each lot of fertilisers. Total organic carbon (TOC), total extracted carbon (TEC), humified organic carbon $[(\mathrm{HA}+\mathrm{FA})-\mathrm{C}]$, total $\mathrm{N}$, total $\mathrm{P}$ and heavy metal contents were determined using methods of Page et al. (1982). Since we did not find differences among composts throughout the years, the mean of the compost properties (mean \pm standard deviation) are reported (Table 1). As regards the commercial fertiliser, we relied on the chemical contents reported by the manufacturer.

At vetch termination, the aboveground biomass weight was measured and samples were dried for $48 \mathrm{~h}$ at $70^{\circ} \mathrm{C}$ and then weighted again. The total $\mathrm{N}$ content $(\%)$ of each biomass sample was determined by LECO analyser (dry combustion), allowing the calculation of the above soil biomass $\mathrm{N}$ ( $\mathrm{N}$ content $\times$ biomass dry weight). Then, the $\mathrm{N}$ supplied by vetch to the melon crop was determined according to all the above considerations and assumptions (Shipley et al., 1992; Sullivan, 1998).
Harvest of melon occurred on $8^{\text {th }}$ and $5^{\text {th }}$ August 2012 and 2013 , respectively, with a cropping cycle of 91 days in both cases. At harvest time, for each plot of $70 \mathrm{~m}^{2}(14 \times 5 \mathrm{~m})$, total and marketable yields $\left(\mathrm{Mg} \mathrm{ha}^{-1}\right)$, aboveground biomass $\left(48 \mathrm{~h}\right.$ at $70^{\circ} \mathrm{C} ; \mathrm{Mg}$ $\mathrm{ha}^{-1}$ ) and fruits number per square meter were determined from a $2.6 \mathrm{~m}^{2}$ area in the middle of the plot. The harvested melon was collected by hand and weighed to determine average fruit weights. At each harvest, quality parameters were measured on a sample of the yield obtained from at least four plants per plot. In particular, the following parameters were determined: fruit and plant $\mathrm{N}$ content; fruit moisture content (through pulp dry matter determination at $70^{\circ} \mathrm{C}$ till constant weight); and total soluble solids content in the juice of two fruits, measured with a refractometer and expressed as ${ }^{\circ}$ Brix. The following indices were, then, calculated: i) nitrogen harvest index (NHI, \%), as the ratio between $\mathrm{N}$ uptake by the fruits and $\mathrm{N}$ uptake by the plant; ii) nitrogen utilisation efficiency (NUE, $\mathrm{kg} \mathrm{kg}^{-1}$ ), as the ratio between total yield and total $\mathrm{N}$ uptake. The terminology of these $\mathrm{N}$ efficiency parameters is in accordance with Delogu et al. (1998). Moreover, at mid-length on the most recently matured leaves from approximately 5 randomly selected plants from each plot, soil plant analysis development (SPAD) readings were taken with a hand-held chlorophyll meter (Minolta SPAD502, Spectrum Technologies, Plainfield, Ill.). On the same leaves, melon petiole sap nitrate content was recorded with a Nitrachek reflectometer (Eijkelkamp, Giesbeek, Netherlands).

At the end of the experimental trial, to determine the cumulative effects of ASC management and organic fertilisation strategies, the overall soil conditions were assessed. In particular, at the 2013 harvest time, five random soil samples $(0-30 \mathrm{~cm}$ depth) were taken from each elementary plot, air dried, ground to pass a 2-mm sieve and then analysed. The following parameters were determined: total nitrogen content $\left(\mathrm{N} ; \mathrm{g} \mathrm{kg}^{-1}\right)$, by the Kjeldahl method; soil nitrate $\left(\mathrm{NO}_{3}{ }^{-}-\mathrm{N} ; \mathrm{mg} \mathrm{kg}^{-1}\right)$, extracted by $2 \mathrm{M} \mathrm{KCl}(1: 10 \mathrm{w} / \mathrm{v})$ and measured by a continuous flow colorimeter according to Henriksen and Selmer-Olsen (1970); TOC $\left(\mathrm{g} \mathrm{kg}^{-1}\right)$ by using the

Table 1. Chemical characteristics of the commercial humified fertiliser, anaerobic digestate fertiliser, and composted municipal organic wastes.

\begin{tabular}{llccc} 
& & \multicolumn{3}{c}{ Organic fertilisers } \\
Parameters & & CHF & AD & MSW \\
Total N & $\left(\mathrm{g} \mathrm{kg}^{-1}\right)$ & 25 & $30.3 \pm 1.04$ & $26.2 \pm 1.67$ \\
Total P & $\left(\mathrm{g} \mathrm{kg}^{-1}\right)$ & 12 & $1.17 \pm 0.08$ & $0.85 \pm 0.26$ \\
\hline Total K & $\left(\mathrm{g} \mathrm{kg}^{-1}\right)$ & 12 & $11.2 \pm 1.01$ & $1.20 \pm 0.31$ \\
TOC $^{\mathrm{a}}$ & $\left(\mathrm{g} \mathrm{kg}^{-1}\right)$ & 250 & $192.0 \pm 4.95$ & $265.7 \pm 12.7$ \\
\hline TEC $^{\mathrm{b}}$ & $\left(\mathrm{g} \mathrm{kg}^{-1}\right)$ & - & $118.8 \pm 7.21$ & $165.0 \pm 10.6$ \\
$(\mathrm{HA}+\mathrm{FA})-\mathrm{C}^{\mathrm{c}}$ & $\left(\mathrm{g} \mathrm{kg}^{-1}\right)$ & 70 & $90.1 \pm 2.12$ & $125.7 \pm 3.07$ \\
\hline $\mathrm{C} / \mathrm{N}$ & & 11 & 6.33 & 10.14 \\
$\mathrm{pH}$ & & 7.9 & $7.63 \pm 0.30$ & $8.62 \pm 0.37$ \\
\hline $\mathrm{Moisture}$ & $\%$ & 15 & $66.4 \pm 0.21$ & $47.92 \pm 0.56$ \\
$\mathrm{Cu}$ & $\left(\mathrm{mg} \mathrm{kg}^{-1}\right)$ & 130 & $431 \pm 37.1$ & $125.1 \pm 11.6$ \\
\hline $\mathrm{Zn}$ & $\left(\mathrm{mg} \mathrm{kg}^{-1}\right)$ & 210 & $65.9 \pm 4.8$ & $269.2 \pm 45.0$ \\
$\mathrm{Ni}$ & $\left(\mathrm{mg} \mathrm{kg}^{-1}\right)$ & - & $10.5 \pm 0.65$ & $6.15 \pm 2.0$ \\
\hline $\mathrm{Pb}$ & $\left(\mathrm{mg} \mathrm{kg}^{-1}\right)$ & - & $0.84 \pm 0.12$ & $33.8 \pm 10.5$ \\
$\mathrm{Cd}$ & $\left(\mathrm{mg} \mathrm{kg}^{-1}\right)$ & - & $<0.05$ & $<0.05$ \\
\hline $\mathrm{Cr}$ & $\left(\mathrm{mg} \mathrm{kg}^{-1}\right)$ & - & $3.03 \pm 0.07$ & $<0.05$ \\
\hline
\end{tabular}

$\mathrm{CHF}$, commercial humified fertiliser; $\mathrm{AD}$, anaerobic digestate fertiliser; MSW, composted municipal organic wastes; TOC, total organic carbon; TEC, total extracted carbon; (HA+FA)-C, humified organic carbon. Reported values are the mean of the two years analytical results \pm standard deviation (AD and MSW) or those provided by the manufacturer (CHF). 
Walkley-Black method (Walkley and Black, 1934). All the plant and soil laboratory tests were carried out in triplicate in order to control intra-laboratory variability.

\section{Statistical analysis}

Before analysis, the Levene test was performed to test the homogeneity of error variances and no data transformation was needed. A combined analysis of variance over the two years was carried out on all the studied parameters. ASC management, fertiliser and year were included as fixed effects, whereas block was included as random effect. When significant effects of year, management and fertiliser and their interactions were found, SNK post hoc test was performed for mean comparisons. The pairwise comparisons between couple of cover factors were processed by the exact Mann-Whitney post hoc test.

PROC BOXPLOT procedure was used to generate box plot for treatment interactions of crop nitrate content over the trial years, providing quantitative information about the variable including its mean, median, quartiles, minimum and maximum.

The selected analyses were performed by using the StatSoft Statistica 7 for ANOVA.

\section{Results}

\section{Meteorological conditions}

Mean temperature value in year 1 (November 2011-August 2012) was close to that of year $2\left(16.2\right.$ and $16.3^{\circ} \mathrm{C}$, respectively; Figure 1). Moreover, in both years the mean temperature was higher compared to the long-term average of $15.2^{\circ} \mathrm{C}$. Mean total rainfall during year 1 was slightly lower than in year 2 (392 and 412 $\mathrm{mm}$, respectively), and compared to the 1981-2010 average of 401 $\mathrm{mm}$.

\section{Experimental fertilisers and nitrogen supplying by vetch}

The anaerobic digestate had higher values for total $\mathrm{N}$, available $\mathrm{P}$, and exchangeable $\mathrm{K}$ than MSW (Table 1). Conversely, the AD contained lower TOC, TEC, $(\mathrm{HA}+\mathrm{FA})-\mathrm{C}$, and a lower $\mathrm{C} / \mathrm{N}$ ratio compared to the compost, which showed a TOC content comparable to that of the commercial fertiliser. Although the MSW was obtained by composting the organic fraction of municipal solid wastes, its heavy metal contents [i.e. copper $(\mathrm{Cu})$, zinc $(\mathrm{Zn})$, nickel $(\mathrm{Ni})$, lead $(\mathrm{Pb})$, cadmium $(\mathrm{Cd})$ and Chromium $(\mathrm{Cr})]$ were below the allowable limits for mixed wastes compost, according to Italian fertilisers legislation (Legislative Decree n. 75; Italian Regulation, 2010). A similar heavy metal concentration was found in AD, with the exception of $\mathrm{Cu}$, which was higher than compost thresholds.

As far as the comparison between RC and GM is concerned, substantial differences in the ASC above soil biomass $\mathrm{N}$ were found in Year 2 (Table 2). In this year, RC showed higher N supplying potential by vetch to melon crop than in Year 1 .

\section{Crop performances}

The output of the analysis of variance for yield performance and quality are reported in Tables 3 and 4 . It revealed significant main effects of year, cover crop management strategy and fertiliser treatments on yield, yield quality, $\mathrm{N}$ status and efficiency of melon crop (except ASC management effect on average marketable fruit weight, NUE and NHI).

The three-way interactions Year $\times$ ASC $\times$ F had a significant effect (except for plant nitrate content), indicating a year dependence of ASC managements on the tested variables for each fertiliser strategy applied. For the nitrate content, all the two-way interactions were significant.

Table 2. Effects of cover crop management on vetch above soil biomass nitrogen and potential of nitrogen supplying by vetch to the melon crop in year 1 and year 2.

\begin{tabular}{|c|c|c|c|c|}
\hline $\begin{array}{l}\text { Cover crop } \\
\text { management }\end{array}$ & $\begin{array}{l}\text { Above soil biomass } \\
\text { N of vetch } \\
\left(\mathrm{Kg} \mathrm{ha}^{-1}\right)\end{array}$ & $\begin{array}{c}\text { N supplying potential } \\
\text { of vetch } \\
\left(\mathrm{Kg} \mathrm{ha}^{-1}\right)\end{array}$ & $\begin{array}{c}\text { Above soil biomass } \\
\mathrm{N} \text { of vetch } \\
\left(\mathrm{Kg} \mathrm{ha}^{-1}\right)\end{array}$ & $\begin{array}{l}\text { N supplying potential } \\
\text { of vetch } \\
\left(\mathrm{Kg} \mathrm{ha}^{-1}\right)\end{array}$ \\
\hline GM & $199 \pm 25.8$ & $100 \pm 12.9$ & $189 \pm 21.9$ & $95 \pm 10.9$ \\
\hline $\mathrm{RC}$ & $184 \pm 19.7$ & $18.45 \pm 1.97$ & $232 \pm 41.8$ & $23.24 \pm 4.19$ \\
\hline Means & 192 & 59.2 & 210 & 59.1 \\
\hline
\end{tabular}

$\mathrm{N}$, nitrogen; GM, green manure; RC, roller-crimper. Values are the mean of three values for each year \pm SD and are presented by GM and RC vetch agro-ecological service crop management.

Table 3. Analysis of variance for the effect of agro-ecological service crop management and organic fertiliser treatments on yield performance.

\begin{tabular}{|c|c|c|c|c|c|c|}
\hline & $\begin{array}{l}\text { Total } \\
\text { yield }\end{array}$ & $\begin{array}{l}\text { Marketable } \\
\text { yield }\end{array}$ & $\begin{array}{l}\text { Average } \\
\text { fruit wt }\end{array}$ & $\begin{array}{c}\text { Average } \\
\text { marketable fruit wt }\end{array}$ & $\begin{array}{l}\text { Number of } \\
\text { fruits }\end{array}$ & $\begin{array}{l}\text { Plant } \\
\text { biomass }\end{array}$ \\
\hline Year & $* * *$ & $* * *$ & $* * *$ & $* * *$ & $* * *$ & $* * *$ \\
\hline ASC & $* * *$ & $* * *$ & $*$ & ns & $* *$ & $* * *$ \\
\hline $\mathrm{F}$ & $* * *$ & $* *$ & $* * *$ & $* * *$ & $* * *$ & $* * *$ \\
\hline Year $\times$ ASC & $* * *$ & $* * *$ & $* * *$ & $* * *$ & $* * *$ & $* * *$ \\
\hline Year $\times F$ & $* * *$ & $* * *$ & $* * *$ & $* * *$ & $* * *$ & $* * *$ \\
\hline $\mathrm{ASC} \times \mathrm{F}$ & $* * *$ & $* * *$ & $* * *$ & $* * *$ & $* * *$ & $* * *$ \\
\hline Year $\times \mathrm{ASC} \times \mathrm{F}$ & $* * *$ & $* * *$ & $* * *$ & $* * *$ & $* * *$ & $* * *$ \\
\hline
\end{tabular}

ASC, agro-ecological service crop; F, organic fertiliser treatments; ns, not significant. 


\section{Melon yield and biomass}

The CHF fertiliser showed the significantly highest total fresh yield when no ASC was included in the rotation (FA) in Year 2 (Table 5), being comparable to result of CHF with RC, followed by CHF and N0 in GM strategy. By contrast, MSW showed the lowest yield value with GM in Year 1, followed by RC-N0 combination. In Year $2 \mathrm{CHF}$ also showed the significantly highest number of fruits per ha in GM and RC, along with MSW in FA and GM managements (mean of 35,704 fruits per ha), whereas in Year $1 \mathrm{MSW}$ showed the lowest value with GM (along with N0 with RC: 8414 and 8018 fruits per ha, respectively; Figure 2). Moreover, in Year 1 the FA-CHF treatments combination recorded the highest average fruit weight, whereas in Year 2 the CHF and MSW treatment under FA management determined the significantly lowest average fruit weight, along with the MSW with GM strategy (Table 5).

Among the ASC strategies, the RC management showed the same production level of FA in both the years, except for the CHF and N0 treatments in Year 1, and MSW in Year 2, which were significantly lower than in FA. Furthermore, in RC - Year 2, the MSW and N0 showed significantly lower yields, average fruit weight (Table 5) and number of fruits (Figure 2) than CHF and AD, the last one being characterised by intermediate values. As far as the marketable yield is concerned, the compared treatments showed a noticeable reduction in comparison to the total yields in FA for CHF in Year $1(38 \%)$ and Year $2(30 \%)$, and for N0 in Year 2 $(21 \%)$, in GM for N0 in Year $2(36 \%)$, in RC for CHF in Year 1 and Year $2(43 \%$ and $13 \%$, respectively), and MSW in Year 1

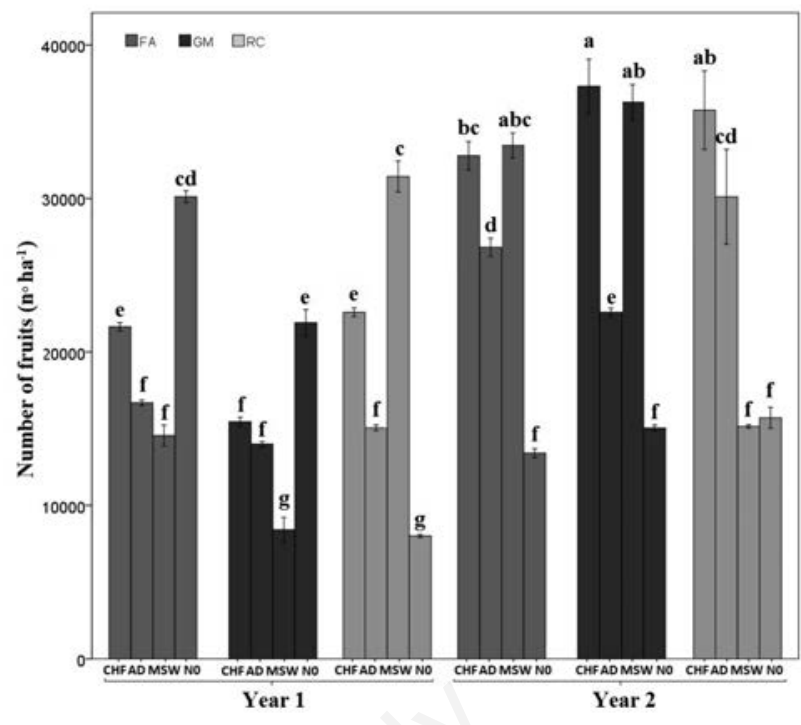

Figure 2. Effect of agro-ecological service crop management (FA, fallow; GM, green manure; RC, roller-crimper), and organic fertiliser treatments (CHF, commercial humified fertiliser; AD, anaerobic digestate fertiliser; MSW, organic composted municipal solid wastes; N0, unfertilised control) on number of fruits $\left(n^{\circ}\right.$ $\mathrm{ha}^{-1}$ ). The bars with different letters are significantly different according to SNK at the $\mathbf{P} \leq \mathbf{0 . 0 5}$ probability level.

Table 4. Analysis of variance for the effect of agro-ecological service crop management and organic fertiliser treatments on yield quality, soil plant analysis development reading values, leaves nitrate contents and nitrogen efficiency indices of melon crop.

\begin{tabular}{|c|c|c|c|c|c|}
\hline & Total soluble solids & SPAD & Nitrate content & NUE & NHI \\
\hline Year & $* * *$ & $* * *$ & $* * *$ & $* * *$ & $* * *$ \\
\hline ASC & $* * *$ & $* * *$ & $* * *$ & ns & ns \\
\hline $\mathrm{F}$ & $* * *$ & $* * *$ & $* * *$ & $* *$ & $* * *$ \\
\hline Year $\times$ ASC & $* * *$ & $*$ & $* * *$ & $* *$ & $* *$ \\
\hline Year $\times F$ & $* * *$ & $*$ & $* *$ & ns & ns \\
\hline $\mathrm{ASC} \times \mathrm{F}$ & $* * *$ & $* * *$ & $* * *$ & ns & ns \\
\hline Year $\times \mathrm{ASC} \times \mathrm{F}$ & $* * *$ & $* * *$ & ns & $* *$ & $* *$ \\
\hline
\end{tabular}

SPAD, soil plant analysis development; NUE, nitrogen utilisation efficiency; NHI, nitrogen harvest index; ASC, agro-ecological service crop; F, organic fertiliser treatments; ns, not significant.

Table 5. Effects of agro-ecological service crop management and organic fertiliser treatments on total yield $\left(\mathrm{Mg} \mathrm{ha}^{-1}\right)$ and average fruit weight $(\mathbf{k g})$.

\begin{tabular}{|c|c|c|c|c|c|c|c|c|c|}
\hline & \multicolumn{4}{|c|}{ Total fresh yield $\left(\mathrm{Mg} \mathrm{ha}^{-1}\right)$} & \multicolumn{4}{|c|}{ Average fruit weight (kg) } \\
\hline & & FA & GM & $\mathrm{RC}$ & Mean & FA & GM & $\mathrm{RC}$ & Mean \\
\hline \multirow[t]{5}{*}{ Year 1} & $\mathrm{CHF}$ & $67.0^{c}$ & $50.1^{\mathrm{dg}}$ & $45.9 \mathrm{ei}$ & 54.3 & $5.38^{\mathrm{a}}$ & $3.26^{\mathrm{d}}$ & $2.05^{\mathrm{i}}$ & 3.56 \\
\hline & $\mathrm{AD}$ & $49.3^{\mathrm{dg} g}$ & $52.7^{\mathrm{df}}$ & $45.2^{\mathrm{fi}}$ & 49.1 & $3.19^{d}$ & $3.55^{\mathrm{c}}$ & $2.94 \mathrm{e}$ & 3.22 \\
\hline & MSW & $48.0^{\mathrm{dh}}$ & $21.1^{\mathrm{m}}$ & $51.9^{\mathrm{df}}$ & 40.3 & $3.14^{\mathrm{de}}$ & $2.74^{\mathrm{f}}$ & $3.07^{\mathrm{de}}$ & 2.98 \\
\hline & No & $58.0^{\mathrm{d}}$ & $53.5^{\mathrm{df}}$ & $29.4^{1}$ & 46.9 & $2.45^{\text {gh }}$ & $2.32^{\mathrm{h}}$ & $3.82^{\mathrm{b}}$ & 2.86 \\
\hline & Mean & 55.6 & 44.3 & 43.1 & 47.7 & 3.54 & 2.97 & 2.97 & 3.16 \\
\hline \multirow[t]{5}{*}{ Year 2} & $\mathrm{CHF}$ & $82.5^{\mathrm{a}}$ & $70.0^{\mathrm{bc}}$ & $76.7^{\mathrm{ab}}$ & 76.4 & $1.58^{\mathrm{mo}}$ & $2.94^{\mathrm{e}}$ & $2.59^{f g}$ & 2.37 \\
\hline & $\mathrm{AD}$ & $53.0^{\mathrm{df}}$ & $46.2^{\mathrm{ei}}$ & $58.0^{\mathrm{d}}$ & 52.4 & $1.79^{\ln }$ & $1.85^{\mathrm{I}}$ & $2.44^{\text {gh }}$ & 2.00 \\
\hline & MSW & $55.7^{\mathrm{de}}$ & $58.0^{\mathrm{d}}$ & $39.9^{\mathrm{hi}}$ & 51.2 & $1.4^{0}$ & $1.50^{\mathrm{no}}$ & $1.83^{1}$ & 1.59 \\
\hline & N0 & $42.3^{\mathrm{gi}}$ & $70.8^{\mathrm{bc}}$ & $37.6^{\mathrm{i}}$ & 50.2 & $1.74^{\mathrm{lm}}$ & $1.82^{1}$ & $1.88^{1}$ & 1.81 \\
\hline & Mean & 58.3 & 61.3 & 53.0 & 57.5 & 1.62 & 2.03 & 2.19 & 1.94 \\
\hline Total mean & & 57.0 & 52.8 & 48.1 & 52.6 & 2.58 & 2.50 & 2.58 & 2.55 \\
\hline
\end{tabular}

FA, fallow; GM, green manure; RC, roller-crimper; CHF, commercial humified fertiliser; $\mathrm{AD}$, anaerobic digestate; MSW, composted municipal solid wastes; $\mathrm{N}$, unfertilised control. ${ }^{\mathrm{a}-0} \mathrm{Means}$ of agro-ecological service crop managements and organic fertiliser treatments followed by different letters within rows are significantly different $(\mathrm{SNK} ; \mathrm{P}<0.05)$. 
(55\%; Table 6). The marketable fruits recorded the highest average weight in Year 1 under GM management with $\mathrm{AD}$ and $\mathrm{CHF}$, and in $\mathrm{RC}-\mathrm{N} 0$ and FA-AD combinations, whereas the lowest values were obtained in Year 2 for AD and MSW under FA management.

The produce quality was assessed through determination of total soluble solids content (Figure 3A).

The AD strategy showed the highest ${ }^{\circ}$ Brix value with $\mathrm{RC}$ in Year $1(13.4 \pm 0.6)$ and FA in Year 2, which were not significantly different from $\mathrm{AD} \times \mathrm{GM}, \mathrm{MSW} \times \mathrm{RC}$, and $\mathrm{CHF}$ and $\mathrm{AD}$ with $\mathrm{FA}$ in Year 1, as well as $\mathrm{CHF} \times \mathrm{FA}$ in Year 2. Conversely, the $\mathrm{CHF} \times \mathrm{RC}$ treatment combination showed the lowest ${ }^{\circ}$ Brix values in Year 1 and Year 2 (9.6 and 10.6, respectively), comparable to AD and MSW with GM in Year 2 (10.0 and 10.6, respectively).

Compared treatments showed different behaviour in the two experimental years for plant fresh biomass (Figure 3B). In particular the $\mathrm{AD} \times \mathrm{GM}$ treatment showed the highest plant biomass in Year 1 (48.2 $\left.\mathrm{Mg} \mathrm{ha}^{-1}\right)$, whereas in Year 2 it showed value significantly lower than all the other treatments $\left(13.6 \mathrm{Mg} \mathrm{ha}^{-1}\right)$ except for the MSW $\times$ RC one. Although the N0 strategy showed the lowest biomass with RC management in Year $1\left(7.4 \mathrm{Mg} \mathrm{ha}^{-1}\right)$ it showed higher performance than MSW with GM (204\%), and in Year 2 than MSW and AD with GM (by 18 and 44\%, respectively), as well as MSW with RC (30\%). The CHF strategy showed stable biomass production in Year $2\left(23.3 \pm 1.5 \mathrm{Mg} \mathrm{ha}^{-1}\right)$ and the significantly highest value but comparable with the AD-RC treatment combination within the same year.

\section{Crop nitrogen status and nitrogen efficiency indices}

SPAD determination showed the highest values in AD-RC and MSW-GM treatments in Year 2, along with CHF-GM in both years, and $\mathrm{AD}$ with FA and $\mathrm{RC}$ in Year 1 (Table 7). The lowest value was recorded in N0-FA treatment in Year 1, along with MSW and $\mathrm{N} 0$ in combination with FA in Year 2. In particular, the N0 strategies showed lower SPAD values than the other F ones, reaching the lowest values in FA management. Nitrogen utilisation efficiency (NUE) was statistically similar in most of the compared treatments in the two experimental years (Table 8). More in depth, significantly lower values were recorded in FA management of Year 1, with the exception of N0 (64.9 vs 36.1 as average value of other F strategies), and in AD under GM management in Year 1. Similarly to NUE, the significantly highest values of NHI index were recorded in Year 2, with the exception of RC-N0 (Table 9), whereas RC-AD showed the lowest NHI index value in Year 1.

The nutritional status of melon crop was also detected by
A

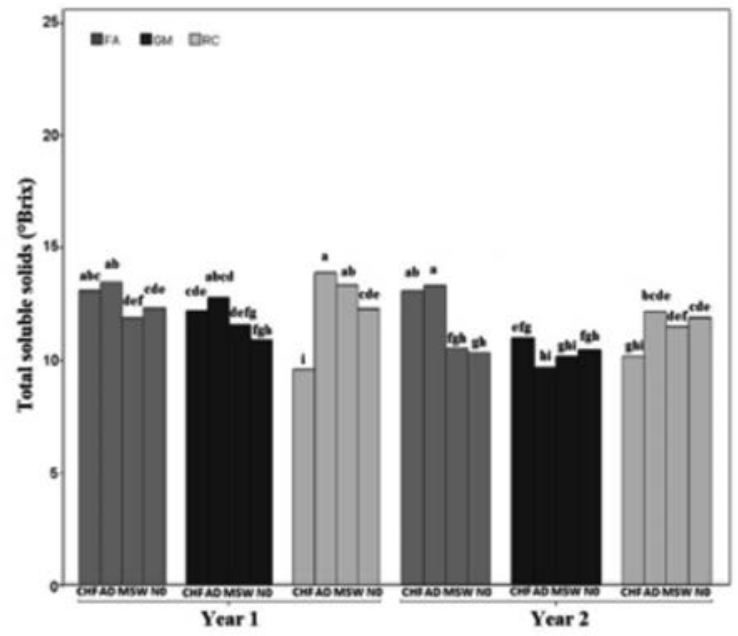

B

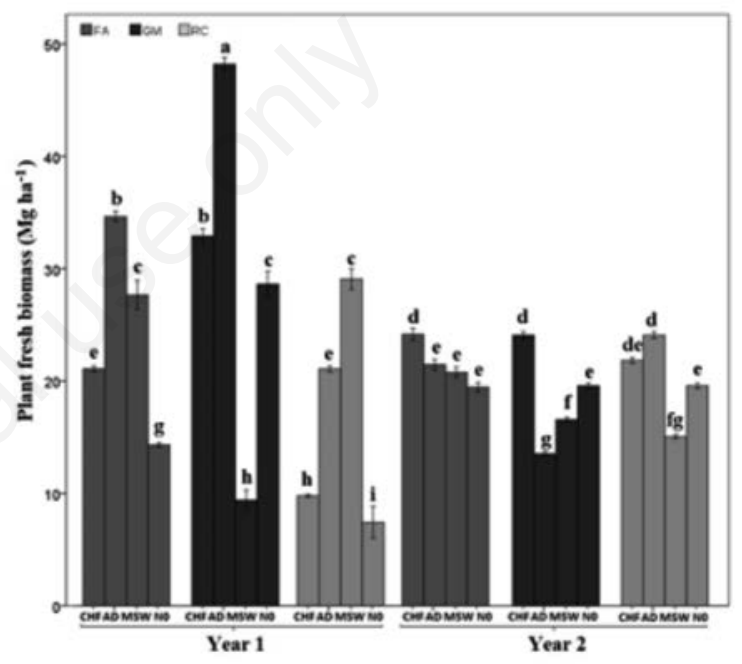

Figure 3. Effect of agro-ecological service crop management (FA, fallow; GM, green manure; RC, roller-crimper) and organic fertiliser treatments (CHF, commercial humified fertiliser; $A D$, anaerobic digestate fertiliser; MSW, organic composted municipal solid wastes; N0, unfertilised control) on (A) total soluble solids $\left({ }^{\circ} \mathrm{Brix}\right)$ and on $(\mathrm{B})$ plant fresh biomass $\left(\mathrm{Mg} \mathrm{ha}^{-1}\right)$. The bars with different letters are significantly different according to SNK at the $\mathbf{P} \leq \mathbf{0 . 0 5}$ probability level.

Table 6. Effects of agro-ecological service crop management and organic fertiliser treatments on marketable yield $\left(\mathrm{Mg} \mathrm{ha}^{-1}\right)$ and marketable fruit weight $(\mathrm{kg})$ of melon crop.

\begin{tabular}{|c|c|c|c|c|c|c|c|c|c|}
\hline & \multicolumn{4}{|c|}{ Marketable fresh yield $\left(\mathrm{Mg} \mathrm{ha}^{-1}\right)$} & \multicolumn{3}{|c|}{ Marketable average fruit weight } & \multirow{2}{*}{$\begin{array}{l}(\mathrm{kg}) \\
\text { Mean }\end{array}$} \\
\hline & & FA & GM & $\mathrm{RC}$ & Mean & FA & GM & RC & \\
\hline \multirow[t]{5}{*}{ Year 1} & $\mathrm{CHF}$ & $41.4^{\mathrm{dh}}$ & $50.1^{\mathrm{cf}}$ & $26.1^{\mathrm{im}}$ & 39.2 & $2.90^{\mathrm{cd}}$ & $3.26^{\mathrm{ab}}$ & $1.99^{9}$ & 2.72 \\
\hline & $\mathrm{AD}$ & $49.3^{\mathrm{cf}}$ & $52.7^{\text {be }}$ & $45.2^{\mathrm{cg}}$ & 49.1 & $3.28^{\mathrm{ab}}$ & $3.55^{\mathrm{a}}$ & $2.94^{\mathrm{cd}}$ & 3.25 \\
\hline & MSW & $48.0^{\mathrm{cf}}$ & $21.1^{\mathrm{m}}$ & $23.6^{\mathrm{lm}}$ & 30.9 & $3.14^{\mathrm{bc}}$ & $2.74^{\mathrm{de}}$ & $1.68^{\mathrm{gi}}$ & 2.52 \\
\hline & No & $56.5^{\mathrm{ac}}$ & $53.5^{\text {be }}$ & $29.4^{\mathrm{hm}}$ & 46.4 & $1.88^{\text {gh }}$ & $2.32^{\mathrm{f}}$ & $3.48^{\mathrm{a}}$ & 2.56 \\
\hline & Mean & 48.8 & 44.3 & 31.1 & 41.4 & 2.80 & 2.97 & 2.52 & 2.76 \\
\hline \multirow[t]{5}{*}{ Year 2} & CHF & $57.7^{\mathrm{ac}}$ & $70.0^{\mathrm{a}}$ & $65.8^{\mathrm{ab}}$ & 64.5 & $1.79^{\text {gh }}$ & $2.30^{\mathrm{f}}$ & $2.59^{\mathrm{ef}}$ & 2.22 \\
\hline & $\mathrm{AD}$ & $52.3^{\text {be }}$ & $46.2^{\mathrm{cg}}$ & $58.0^{\mathrm{ac}}$ & 52.2 & $1.37^{\mathrm{i}}$ & $1.85^{\text {gh }}$ & $2.44^{\mathrm{f}}$ & 1.89 \\
\hline & MSW & $55.7^{\text {ad }}$ & $58.0^{\mathrm{ac}}$ & $39.9 \mathrm{ei}$ & 51.2 & $1.44^{\mathrm{i}}$ & $1.50^{\mathrm{hi}}$ & $1.83^{\mathrm{gh}}$ & 1.59 \\
\hline & No & $33.6^{\mathrm{gm}}$ & $45.2^{\mathrm{cg}}$ & $37.6^{\mathrm{fl}}$ & 38.8 & $1.83^{\text {gh }}$ & $1.82^{\mathrm{gh}}$ & $1.88^{g h}$ & 1.84 \\
\hline & Mean & 49.8 & 54.9 & 50.3 & 51.7 & 1.61 & 1.87 & 2.19 & 1.89 \\
\hline Total mean & & 49.3 & 46.9 & 40.7 & 46.5 & 2.42 & 2.36 & 2.33 & \\
\hline
\end{tabular}

FA, fallow; GM, green manure; RC, roller-crimper; CHF, commercial humified fertiliser; AD, anaerobic digestate; MSW, composted municipal solid wastes; N0, unfertilised control. a-mMeans of agro-ecological service crop managements and organic fertiliser treatments followed by different letters within rows are significantly different (SNK; $\mathrm{P}<0.05)$. 
determining the leaves nitrate content (Figure 4), which showed a value significantly higher by $255 \%$ in the $\mathrm{GM} \times \mathrm{CHF}$ interaction as compared with all the other ASC management $\times$ fertiliser interactions. The latter had no significant differences among them, showing a broad overlap of data distributions. In addition, the interquartile range of the box plot for $\mathrm{GM} \times \mathrm{CHF}$ (indicating how spread out the middle values are) better shows the difference with $\mathrm{FA} \times \mathrm{CHF}$ and $\mathrm{RC} \times \mathrm{CHF}$ interactions. Quite different distributions for $\mathrm{AD}$ and $\mathrm{N} 0$ in combination with GM and RC, than with FA treatment can also be observed. Moreover, the $\mathrm{RC} \times \mathrm{MSW}$ interaction presented a wider distribution in comparison with the $\mathrm{FA} \times \mathrm{MSW}$ and $\mathrm{GM} \times \mathrm{MSW}$ ones.

\section{Soil properties}

The output of the analysis of variance for some soil properties assessed at the end of the field trial, revealed significant main effects of ASC management and fertiliser treatments. In addition, the two-way interactions where all significant (data not shown). As far as soil TOC is concerned, treatments where the fertilisers were applied (namely, CHF, AD and MSW) showed higher values than the not fertilised one (N0) (Table 10). In CHF the RC strategy determined TOC content higher by $7.3 \%$ than GM and similar to the FA treatment. In N0 the RC determined a higher value than FA and the N0-GM treatment had an intermediate value.

The soil $\mathrm{N}$ content was comparable between RC and GM treatments in CHF plots, but lower than FA, whereas in combination with MSW the RC determined a value higher by $18 \%$ than the average of FA and GM strategies. In N0 the worst result was obtained by GM as compared to FA, but being comparable to that of RC.

Soil nitrate content was significantly higher due to GM $\times$ MSW interaction than in all the other cases (Figure 5). Conversely, the MSW in combination with RC determined nitrate higher by $113 \%$ than with FA. The commercial fertiliser in interaction with both GM and RC showed soil nitrate content significantly higher than with FA treatment. Also the AD fertiliser determined the highest nitrate value with GM, being higher by $52 \%$ than the average of $\mathrm{FA} \times \mathrm{AD}$ and $\mathrm{RC} \times \mathrm{AD}$ interactions that were comparable between them. Finally, for N0 treatment the significantly lowest parameter value was observed in interaction with $\mathrm{FA}$, whereas $\mathrm{GM} \times \mathrm{N} 0$ had the highest value.

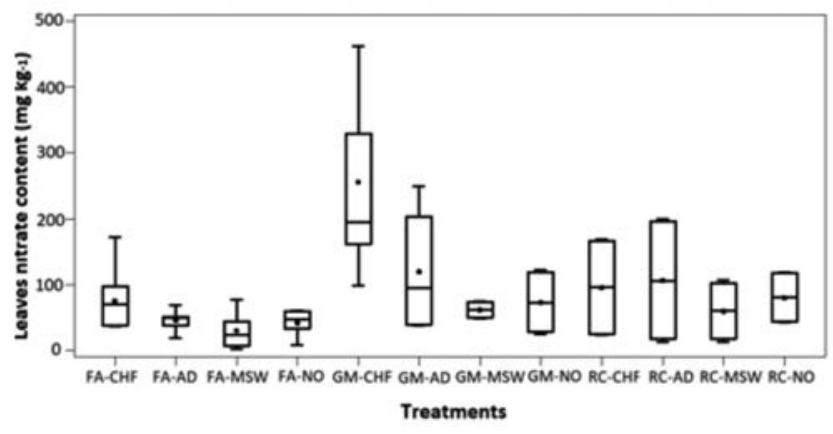

Figure 4. Box plot for treatment interactions of crop nitrate content $\left(\mathrm{mg} \mathrm{kg}^{-1}\right)$ over the trial period. FA, fallow; CHF, commercial humified fertiliser; $A D$, anaerobic digestate fertiliser; MSW, organic composted municipal solid wastes; N0, unfertilised control; GM, green manure; RC, roller-crimper.
Table 7. Effects of agro-ecological service crop management and organic fertiliser treatments on soil plant analysis development reading values.

\begin{tabular}{|c|c|c|c|c|c|}
\hline & \multicolumn{4}{|c|}{ SPAD } \\
\hline & & FA & GM & $\mathrm{RC}$ & Mean \\
\hline \multirow[t]{5}{*}{ Year 1} & $\mathrm{CHF}$ & $23.9^{\text {hi }}$ & $324^{\mathrm{ac}}$ & $29.5^{\mathrm{ce}}$ & 28.6 \\
\hline & $\mathrm{AD}$ & $28.1^{\mathrm{dg} g}$ & $32.4^{\mathrm{ac}}$ & $31.7^{\text {ad }}$ & 30.7 \\
\hline & MSW & $28.5 \mathrm{~d}^{\mathrm{g}}$ & $27.6^{\mathrm{eg}}$ & $28.5^{d g}$ & 28.2 \\
\hline & No & $20.3^{1}$ & $25.5^{\mathrm{fi}}$ & $24.7^{\mathrm{gi}}$ & 23.5 \\
\hline & Mean & 25.2 & 29.5 & 28.6 & 27.8 \\
\hline \multirow[t]{5}{*}{ Year 2} & $\mathrm{CHF}$ & $28.7^{\mathrm{cf}}$ & $33.4^{\mathrm{ab}}$ & $27.8^{\mathrm{eh}}$ & 29.9 \\
\hline & $\mathrm{AD}$ & $26.7^{\text {eh }}$ & $31.8^{\text {ad }}$ & $35.0^{\mathrm{a}}$ & 31.1 \\
\hline & MSW & $23.1^{\mathrm{il}}$ & $34.3^{\mathrm{a}}$ & $28.8^{\mathrm{cf}}$ & 28.7 \\
\hline & No & 22.9il & $25.2^{\mathrm{fi}}$ & $30.4^{\text {be }}$ & 26.2 \\
\hline & Mean & 25.3 & 31.2 & 30.5 & 29.0 \\
\hline \multicolumn{2}{|c|}{ Total mean } & 25.3 & 30.3 & 29.6 & 28.4 \\
\hline
\end{tabular}

SPAD, soil plant analysis development; FA, fallow; GM, green manure; RC, roller-crimper; $\mathrm{CHF}$, commercia humified fertiliser; $\mathrm{AD}$, anaerobic digestate; MSW, composted municipal solid wastes; $\mathrm{N} 0$, unfertilised control. ${ }^{-a}$ Means of agro-ecological service crop managements and organic fertiliser treatments followed by different letters within rows are significantly different (SNK; $\mathrm{P}<0.05)$

Table 8. Effects of agro-ecological service crop management and organic fertiliser treatments on nitrogen utilisation efficiency (kg $\left.\mathbf{k g}^{-1}\right)$.

\begin{tabular}{|c|c|c|c|c|c|}
\hline & \multicolumn{4}{|c|}{ NUE } \\
\hline & & FA & GM & $\mathrm{RC}$ & Mean \\
\hline \multirow[t]{5}{*}{ Year 1} & $\mathrm{CHF}$ & $38.5^{\text {bd }}$ & $44.4^{\text {ad }}$ & $57.8^{\text {ad }}$ & 46.9 \\
\hline & $\mathrm{AD}$ & $32.6^{\mathrm{d}}$ & $34.8^{\mathrm{cd}}$ & $49.2^{\text {ad }}$ & 38.9 \\
\hline & MSW & $37.2^{\text {bd }}$ & $54.1^{\text {ad }}$ & $63.6^{\mathrm{ab}}$ & 51.6 \\
\hline & NO & $64.9^{\mathrm{ab}}$ & $44.6^{\text {ad }}$ & $44.8^{\text {ad }}$ & 51.4 \\
\hline & Mean & 43.3 & 44.5 & 53.9 & 47.2 \\
\hline \multirow[t]{5}{*}{ Year 2} & CHF & $55.0^{\text {ad }}$ & $54.1^{\mathrm{a}}$ & $54.2^{\text {ad }}$ & 54.4 \\
\hline & $\mathrm{AD}$ & $49.5^{\text {ad }}$ & $67.0^{\mathrm{a}}$ & $48.4^{\text {ad }}$ & 54.9 \\
\hline & MSW & $67.3^{\mathrm{a}}$ & $62.5^{\mathrm{ac}}$ & $56.8^{\text {ad }}$ & 62.2 \\
\hline & No & $60.1^{\text {ad }}$ & $72.4^{\text {ad }}$ & $65.4^{\mathrm{ab}}$ & 66.00 \\
\hline & Mean & 58.0 & 64.0 & 56.2 & 59.4 \\
\hline \multicolumn{2}{|c|}{ Total mean } & 50.6 & 54.2 & 55.0 & 53.3 \\
\hline
\end{tabular}

NUE, nitrogen utilisation efficiency; FA, fallow; GM, green manure; RC, roller-crimper; CHF, commercia humified fertiliser; $\mathrm{AD}$, anaerobic digestate; MSW, composted municipal solid wastes; N0, unfertilised control. a-lMeans of agro-ecological service crop managements and organic fertiliser treatments followed by different letters within rows are significantly different $(\mathrm{SNK} ; \mathrm{P}<0.05)$

Table 9. Effects of agro-ecological service crop management and organic fertiliser treatments on nitrogen harvest index $(\%)$.

\begin{tabular}{|c|c|c|c|c|c|}
\hline & \multicolumn{4}{|c|}{ NHI } \\
\hline & & FA & GM & $\mathbf{R C}$ & Mean \\
\hline \multirow[t]{5}{*}{ Year 1} & $\mathrm{CHF}$ & $82.0^{\mathrm{a}}$ & $70.0^{\text {be }}$ & $78.0^{\text {ad }}$ & 76.7 \\
\hline & $\mathrm{AD}$ & $66.9^{d f}$ & $62.3^{\mathrm{ef}}$ & $59.5^{\mathrm{f}}$ & 62.9 \\
\hline & MSW & $68.1^{\mathrm{cf}}$ & $77.0^{\text {ad }}$ & $62.2^{\mathrm{ef}}$ & 69.1 \\
\hline & No & $79 . .^{\mathrm{ab}}$ & $72.1^{\text {ae }}$ & $75.1^{\text {ad }}$ & 75.7 \\
\hline & Mean & 74.2 & 70.4 & 68.7 & 71.1 \\
\hline \multirow[t]{6}{*}{ Year 2} & $\mathrm{CHF}$ & $82.5^{\mathrm{a}}$ & $78.9^{\mathrm{ac}}$ & $75.0^{\text {ad }}$ & 78.8 \\
\hline & $\mathrm{AD}$ & $82.3^{\mathrm{a}}$ & $80.3^{\mathrm{ac}}$ & $81.4^{\mathrm{ab}}$ & 81.3 \\
\hline & MSW & $80.6^{\mathrm{ac}}$ & $78.0^{\text {ad }}$ & $80.3^{\mathrm{ab}}$ & 79.6 \\
\hline & No & $78 . .^{a c}$ & $73.7^{\text {ad }}$ & $67.8^{\mathrm{cf}}$ & 73.5 \\
\hline & Mean & 81.0 & 77.7 & 76.1 & 78.3 \\
\hline & Total mean & 77.6 & 74.0 & 74.4 & 74.7 \\
\hline
\end{tabular}

$\mathrm{NHI}$, nitrogen harvest index; FA, fallow; GM, green manure; RC, roller-crimper; CHF, commercial humified fertiliser; AD, anaerobic digestate; MSW, composted municipal solid wastes; N0, unfertilised control. a-lMeans of agro-ecological service crop managements and organic fertiliser treatments followed by different letters within rows are significantly different (SNK; $\mathrm{P}<0.05$ ). 


\section{Discussion}

\section{Melon yield performance}

Melon total yield was affected, also, by the year factor, as revealed by the significant effect of the three-way interactions, reasonably due to the climatic conditions variation. In particular, the May-August total rainfall was remarkably different in the two cropping cycles, being higher by $44 \%$ in Year 1 than in Year 2 . The mean temperature values in the July-August period, i.e. during the period of high uptake of nutrients by the growing fruits, was higher in Year $1\left(28^{\circ} \mathrm{C}\right)$ than in Year $2\left(26^{\circ} \mathrm{C}\right)$. This could have been a factor determining a higher crop growth (melon is a high heat demanding crop) in Year 1, as showed by plant fresh biomass (Figure 3B), despite yield results were better in the second year than in the first one (Table 5).

Anyway, it is important to point out the different behaviour of the ASC management strategies in interaction with different fertilisers and the consequent yield findings. Among the ASC termination treatments, the greatest yield results were obtained in Year 2 by both $\mathrm{RC}$ and GM in combination with $\mathrm{CHF}$, in accordance to a high number of fruits obtained (Figure 2). However, the CHFGM yield appeared to be more stable from one year to the other, as compared to the CHF-RC combination. This was probably because of the aboveground vetch biomass $\left(6.5 \pm 0.81 \mathrm{t} \mathrm{ha}^{-1}\right.$, on average of two years) quickly mineralised when incorporated into the soil, thus supplying readily available $\mathrm{N}$ amounts in addition to fertilisers (Perdigão et al., 2012). Similarly, Carrera et al. (2004) found that hairy vetch/rye mineralisation allowed a more efficient absorption by sweet corn. By contrast, the lower yield performance observed in the plots with RC, particularly in combination with $\mathrm{N} 0$, might have been the result of less $\mathrm{N}$ supplied by the cover crop with this management strategy during the melon growing cycle (Table 2). In fact, in the RC treatment, only the root biomass was totally available for mineralisation from the beginning of the melon cropping cycle, while the above soil vetch biomass was mineralised in a slow, continuous process, which occurred only in the mulch - soil interface. This may have been combined with a reduction effect on soil temperature determined by the mulch (Teasdale and Mohler, 1993; Altieri et al., 2011) that quite likely affected the vegetable crop growth. This result is in agreement with the findings of Leavitt et al. (2011) for other crops. However, in $\mathrm{RC}$ a share of the $\mathrm{N}$ contained in the cover crop aboveground residues could be available for the next crop in rotation. Similar results were also obtained by Montemurro et al. (2013), who tested the same two vetch management options for zucchini production.
Although in the second year, irrespective of the cover crop management, the CHF treatment showed higher total and marketable yield than the other fertiliser treatments, in both years the marketable melon yield after application of $\mathrm{AD}$ under different cover crop managements was not substantially different, likely suggesting a greater amount of discarded fruits from CHF plots in Year 1 (Table 6).

Similar results were obtained by Montemurro (2010) on lettuce crop, indicating that anaerobic digestates could be a substitute of the most widespread fertilisers (i.e., poultry manure) on organic vegetables. This finding is particularly relevant considering that the dose of all the organic fertilisers were reduced in order to take

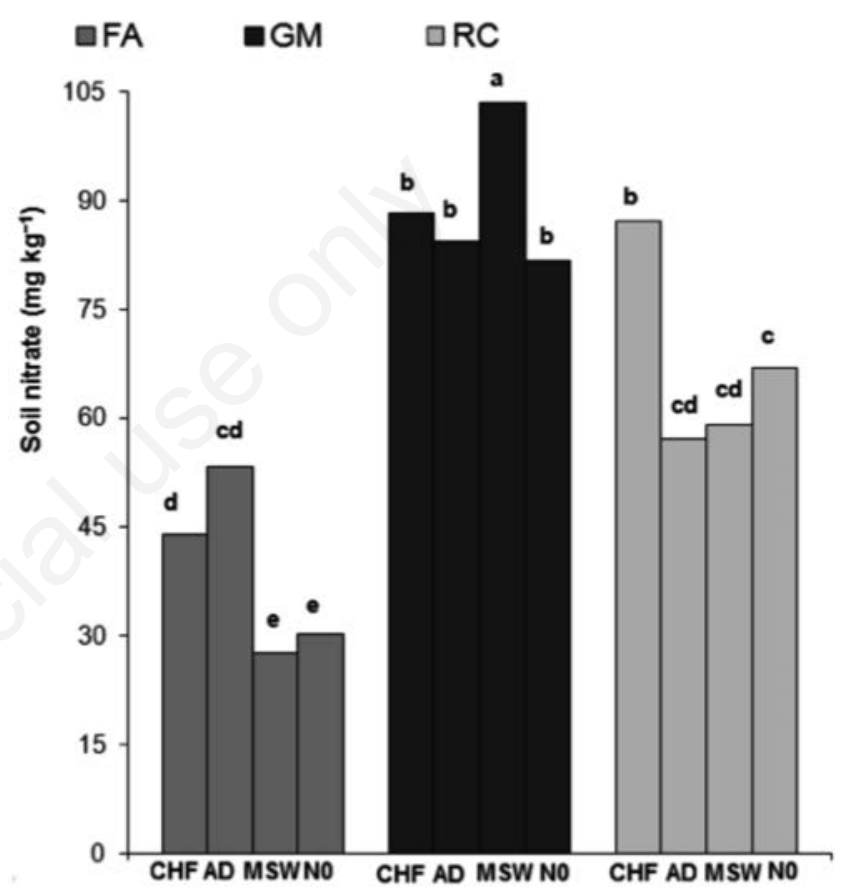

Figure 5. Effect of agro-ecological service crop management (FA, fallow; GM, green manure; RC, roller-crimper) and organic fertiliser treatments (CHF, commercial humified fertiliser; $A D$, anaerobic digestate fertiliser; MSW, organic composted municipal solid wastes; NO, unfertilised control) on soil nitrate content $\left(\mathrm{NO}_{3}^{-}-\mathrm{N}, \mathrm{mg} \mathrm{kg}^{-1}\right)$ at the end of the trial. The bars with different letters are significantly different according to $\mathrm{SNK}$ at the $\mathrm{P} \leq \mathbf{0 . 0 5}$ probability level.

Table 10. Effects of agro-ecological service crop management and organic fertiliser treatments on total organic carbon and total nitrogen content at the end of the field trial.

\begin{tabular}{|c|c|c|c|c|c|c|c|c|c|c|c|c|c|c|}
\hline & FA & GM & $\mathrm{RC}$ & $\begin{array}{l}\text { TOC } \\
\mathrm{CHF}\end{array}$ & AD & MSW & NO & FA & GM & $\mathrm{RC}$ & $\begin{array}{c}\mathbf{N} \\
\mathrm{CHF}\end{array}$ & AD & MSW & NO \\
\hline & $17.0^{\mathrm{a}}$ & $17.1^{\mathrm{a}}$ & $18.2^{\mathrm{a}}$ & $17.7^{\mathrm{b}}$ & $18.1^{\mathrm{ab}}$ & $19.3^{\mathrm{a}}$ & $15.1^{\mathrm{c}}$ & $1.29^{\mathrm{a}}$ & $1.20^{\mathrm{a}}$ & $1.30^{\mathrm{a}}$ & $1.29^{\mathrm{a}}$ & $1.25^{\mathrm{a}}$ & $1.31^{\mathrm{a}}$ & $1.21^{\mathrm{a}}$ \\
\hline CHF & $17.2^{\mathrm{b}}$ & $16.4^{c}$ & $17.6^{\mathrm{b}}$ & & & & & $1.34^{\mathrm{a}}$ & $1.25^{b}$ & $1.29^{b}$ & & & & \\
\hline$A D$ & $18.4^{\mathrm{a}}$ & $17.7^{\mathrm{a}}$ & $18.3^{\mathrm{a}}$ & & & & & $1.33^{\mathrm{a}}$ & $1.19^{a}$ & $1.23^{\mathrm{a}}$ & & & & \\
\hline MSW & $18.6^{\mathrm{ab}}$ & 18.9ab & $20.4^{\mathrm{a}}$ & & & & & $1.27^{\mathrm{b}}$ & $1.21^{b}$ & $1.46^{\mathrm{a}}$ & & & & \\
\hline N0 & $13.6^{\mathrm{b}}$ & $15.4^{\mathrm{ab}}$ & $16.4^{\mathrm{a}}$ & & & & & $1.24^{\mathrm{a}}$ & $1.16^{b}$ & $1.23^{\mathrm{ab}}$ & & & & \\
\hline
\end{tabular}

TOC, total organic carbon; N, nitrogen; FA, fallow; GM, green manure; RC, roller-crimper; CHF, commercial humified fertiliser; AD, anaerobic digestate; MSW, composted municipal solid wastes; N0, unfertilised control. ${ }^{\mathrm{a}-\mathrm{c} M e a n s}$ of agro-ecological service crop managements and organic fertiliser treatments followed by different letters within rows are significantly different (SNK; $\left.\mathrm{P}<0.05\right)$. 
into account the contribution of vetch (except in FA plots). The favourable yield results of $\mathrm{AD}$ were probably due to the great amount of nutrients, confirming the crucial role of the fertiliser composition. Moreover, our findings are comparable to those of Canali et al. (2010), which showed that organic fertilisers and anaerobic digestates had greater mineralisation rates than the compost.

Conversely, the MSW showed the best marketable yield results in Year 2 in interaction with FA and GM. This could be due, once again, to the different meteorological conditions and consequent organic matter mineralisation. The known limited $\mathrm{N}$ mineralisation from compost in the short-term (Diacono and Montemurro, 2011) likely was the factor determining the worst result of MSW in combination with RC (in comparison with the other ASC managements). Moreover, $\mathrm{N}$ immobilisation owed to no-till roller crimper might have occurred (Altieri et al., 2011; Luna et al., 2012). These concurrent conditions likely increased the competition for nutrients between vetch and melon crop in MSW $\times$ RC.

\section{Melon crop quality and nutrient efficiency}

The soluble solids concentration of fruits flesh is one of the most important quality parameters, indicating potential melon sweetness that is commonly evaluated by consumers. It was on average lower in the second trial year (Figure 3A), probably due to abiotic components of the growing environment (e.g., moisture, fertility, temperature). The good parameter results of FA in interaction with $\mathrm{CHF}$ in both years could be explained by taking into account the positive soil tillage influence combined with the $\mathrm{N}$ fertiliser availability. The AD fertiliser significantly affected the total soluble solids content probably due to its great N content. Anyway, this is not in agreement with findings of other authors (Rodríguez et al., 2005).

The higher SPAD values in GM-CHF in comparison with the $\mathrm{RC}-\mathrm{CHF}$ combination, could be influenced by the above discussed increased $\mathrm{N}$ availability from green manure (owed to the incorporated dead biomass) that was probably further increased using the CHF fertiliser (Tables 2, 7-9). The plant biomass and SPAD was also positively influenced by the nutrients availability after the AD application in combination with vetch managements. On the whole, the ASC managements had a positive effect on plant N status, determining the increase of SPAD readings as compared to FA.

Plant nitrate content increased for $\mathrm{CHF} \times \mathrm{GM}$ interaction (Figure 4), thus substantiating the obtained high values of SPAD due to this interaction. The broad overlap of the distributions of the other interactions suggests that differences among them can be interpreted only as a tendency, due to the large within-treatment variance. Moreover, the lower plant nitrate content in the $\mathrm{MSW} \times \mathrm{ASC}$ management interactions than in the CHF ones, confirms MSW results for tomato crop in comparable environmental conditions (Montemurro et al., 2005). Similarly, Song et al. (2010) found that the aboveground plant $\mathrm{N}$ concentration of muskmelon was reduced using compost. This outcome could be further explained by a low mineralisation rate of compost in a short time period.

The lack of significant differences for the NUE index among different ASC management-fertiliser combinations (Table 8), should take into account that GM and $\mathrm{RC}$ received less $\mathrm{N}$ than $\mathrm{FA}$, thus suggesting that the $\mathrm{N}$ derived from the vetch was efficiently used for yield, and no difference in $\mathrm{N}$ utilisation was found among treatments. The highest NHI values were found in the second year, indicating that the $\mathrm{N}$ uptake by the fruits was higher than the $\mathrm{N}$ uptake by the plant, as supported by marketable yield results (Table 6)

\section{Effects of treatments on soil properties}

Positive effects of RC on soil fertility parameters were detected. The TOC content was significantly increased by the flattened mulch in combination with CHF, as compared to GM. This would suggest that such treatments interaction was particularly able to improve carbon sequestration in the soil, maybe due to synergy between reduction of soil disturbance by tillage and favourable CHF composition. As a matter of fact, the rate of soil organic carbon storage in no-tillage increases when cover crops were used (Dabney et al., 2010).

The higher $\mathrm{N}$ content in the soil determined by RC-MSW (compared to GM-MSW) could be explained considering that in this case the high organic matter inputs in soil (such as compost and ASC residues) could have promote greater levels of labile C sources and microbial activity (organic matter decomposition), thus increasing $\mathrm{N}$ supplying capacity than conventional systems (Delate et al., 2008).

As far as soil nitrate content is concerned, our study indicates that $\mathrm{RC} \times \mathrm{AD}$ and $\mathrm{RC} \times \mathrm{MSW}$ interactions were able to reduce nitrate content and, according to Kristensen and Thorup Kristensen (2004), the consequent losses by leaching from the agro-ecosystem could also be reduced. Conversely, the greatest yield results in the GM, compared with the RC treatment, was accompanied by a high soil nitrate content in the GM plots (i.e. GM in interactions with all the fertiliser treatments), so confirming previous studies (Kirchmann and Bergström, 2001). Therefore, the $\mathrm{N}$ fertilisation of melon crop should take into account the biological $\mathrm{N}_{2}$ fixation by vetch and the mineralisation rates after the green manuring (Montemurro et al., 2013). According to Cabello et al. (2009), excessive amounts of $\mathrm{N}$ can cause not only groundwater contamination by nitrates but also negative effects on melon yield quality, as in GM plots (Figure 3A).

\section{Conclusions}

Our study would confirm the positive role of the ASC introduction in the Mediterranean environments. The use of the roller crimper technique, to terminate the vetch by flattening, showed an interesting potential in enhancing soil fertility building services of ASC. Also, yield quality of the roller crimper plots was generally greater than that due to GM management.

The selection and the adequate application to the cropping system of the suitable organic fertilisers (particularly anaerobic digestate) was demonstrated to be an effective tool to mitigate the negative trend of the roller crimper technique on yield.

Overall, our study demonstrated that the proper design of the agro-ecosystems and the smart management of their components (i.e. cover crops and fertilisation), carried out according to an integrated approach based on agro-ecologically sound criteria, allow to obtain favourable ecological services in organic melon. The choice of the correct combination of agro-ecological tools and practices should take into account the soil characteristics and plant requirements in order to sustain valuable production and soil fertility over time, in particular in organic horticultural systems.

\section{References}

Allen RG, Pereira LA, Raes D, Smith M, 1998. Crop evapotranspiration - Guidelines for computing crop water requirements. 
FAO Irrigation and Drainage Paper No. 56, Rome, Italy.

Altieri MA, Lana MA, Bittencourt HV, Kieling AS, Comin JJ, Lovato PE, 2011. Enhancing crop productivity via weed suppression in organic no-till cropping systems in Santa Catarina, Brazil. J. Sustain. Agr. 35:855-69.

Bàrberi $\mathrm{P}, 2002$. Weed management in organic agriculture: Are we addressing the right issues? Weed Res. 42:177-93.

Bhella HS, Wilcox GE, 1986. Yield and composition of muskmelon as influenced by preplant and trickle applied nitrogen. Hortsci. 21:86-8.

Blanco-Canqui H, Claassen MM, Presley DR, 2012. Summer ASCs fix nitrogen, increase crop yield, and improve soil-crop relationships. Agron. J. 104:137-47.

Cabello MJ, Castellanos MT, Romojaro F, Martínez-Madrid C, Ribas F, 2009. Yield and quality of melon grown under different irrigation and nitrogen rates. Agr. Water Manage. 96:866-74.

Campiglia E, Mancinelli R, Radicetti E, 2011. Influence of notillage and organic mulching on tomato (Solanum Lycopersicum L.) production and nitrogen use in the mediterranean environment of central Italy. Sci. Hortic.-Amsterdam 130:588-98.

Canali S, Campanelli G, Ciaccia C, Leteo F, Testani E, Montemurro F, 2013. Conservation tillage strategy based on the roller crimper technology for weed control in Mediterranean vegetable organic cropping systems. Eur. J. Agron. 50:11-8.

Canali S, Ciaccia C, Antichi D, Bàrberi P, Montemurro F, Tittarelli F, 2010. Interactions between green manure and amendment type and rate: Effects on organic potato and soil mineral $\mathrm{N}$ dynamic. J. Food Agr. Environ. 8:537-43.

Canali S, Diacono M, Campanelli G, Montemurro F, 2015. Organic no-till with roller crimpers: agro-ecosystem services and applications in organic mediterranean vegetable productions. Sustain. Agricult. Res. 4:70-9.

Carrera LM, Abdul-Baki AA, Teasdale JR, 2004. ASC management and weed suppression in no-tillage sweet corn production. HortSci. 39:1262--6.

Dabney SM, Delgado JA, Meisinger JJ, Schomberg HH, Liebig MA, Kaspar T, Mitchell J, Reeves W, 2010. Using ASCs and cropping systems for nitrogen management. Chapter 9. In: J.A. Delgado and R.F. Follett (Eds.), Advances in nitrogen management for water quality. Soil and Water Conservation Society, Ankeny, IA, USA.

Delate K, Cambardella C, McKern A, 2008. Effects of organic fertilisation and ASCs on an organic pepper system. HortTechnol. 18:215-26.

Delate K, Cwach D, Chase C, 2012. Organic no-tillage system effects on soybean, corn and irrigated tomato production and economic performance in Iowa, USA. Renew. Agric. Food Syst. 27:49-59.

Delogu G, Cattivelli L, Secchioni N, De Falcis D, Maggiore T, Stanca AM, 1998. Uptake and agronomic efficiency of nitrogen in winterbarley and winter wheat. Eur. J. Agron. 9:1-20.

Diacono M, Montemurro F, 2011. Long-term effects of organic amendments on soil fertility. In: E. Lichtfouse, M. Hamelin, M. Navarrete, P. Debaeke (Eds.), Sustainable agriculture 2, Springer, Berlin, Germany, pp 761-786.

Doorenbos J, Pruitt WO, 1977. Crop water requirements. FAO Irrigation and Drainage Paper No. 24 (revised), Rome, Italy.

Fageria NK, Baligar VC, Bailey BA, 2005. Role of ASCs in improving soil and row crop productivity. Commun. Soil Sci. Plant Anal. 36:2733-57.

Gomiero T, Pimentel D, Paoletti MG, 2008. Energy and environ- mental issues in organic and conventional agriculture. Crit. Rev. Plant Sci. 27:239-54.

Hayden ZD, Brainard DC, Henshaw B, Ngouajio M, 2012. Winter annual weed suppression in rye-vetch ASC mixtures. Weed Technol. 26:818-25.

Henriksen A, Selmer-Olsen AR, 1970. Automatic methods for determining nitrate and nitrite in water and soil extracts. Analyst 95:514-8.

Italian Regulation, 2010. Decreto Legislativo n. 75, 29/04/2010. Riordino e revisione della disciplina in materia di fertilizzanti, a norma dell'articolo 13 della legge 7 luglio 2009, n. 88. G.U. n. $12126 / 05 / 2010$.

Kirchmann H, Bergström L, 2001. Do organic farming practices reduce nitrate leaching? Commun. Soil Sci. Plant Anal. 32:997-1028

Kornecki TS, Price AJ, Raper RL, Arriaga FJ, 2009. New roller crimper concepts for mechanical termination of ASCs in conservation agriculture. Renew. Agr. Food Syst. 24:165-73.

Kremen C, Miles A, 2012. Ecosystem services in biologically diversified versus conventional farming systems: benefits, externalities, and trade-offs. Ecol. Soc. 17:40.

Kristensen HL, Thorup-Kristensen K, 2004. Uptake of $15 \mathrm{~N}$ labeled nitrate by root systems of sweet corn, carrot and white cabbage from 0.2-2.5 meters depth. Plant Soil 265:93-100.

Leavitt MJ, Sheaffer CC, Wyse DL, Allan DL, 2011. Rolled winter rye and hairy vetch ASCs lower weed density but reduce vegetable yields in no-tillage organic production. HortSci. 46:387-95.

Lesueur Jannoyer M, Le Bellec F, Lavigne C, Achard R, Malézieux E, 2011. Choosing ASCs to enhance ecological services in orchards: a multiple criteria and systemic approach applied to tropical areas. Procedia Environ. Sci. 9:104-12.

Lu Y-C, Watkins KB, Teasdale JR, Abdul-Baki AA, 2000. ASCs in sustainable food production. Food Rev. Int. 16:121-57.

Luna JM, Mitchell JP, Shrestha A, 2012. Conservation tillage for organic agriculture: Evolution toward hybrid systems in the western USA. Renew. Agric. Food Syst. 27:21-30.

Masiunas JB. 1998. Production of vegetables using ASC and living mulches - a review. J. Veg. Soil Prod. 4:11-31.

Mazzoncini M, Sapkota TB, Bàrberi P, Antichi D, Risaliti R, 2011. Long-term effect of tillage, nitrogen fertilisation and ASCs on soil organic carbon and total nitrogen content. Soil Till. Res. 114:165-74.

Montemurro F, 2010. Are the organic N fertilising strategies able to improve lettuce yield, use of nitrogen and N status? J. Plant Nutr. 33: 1980-1997.

Montemurro F, Convertini G, Ferri D, Maiorana M, 2005. MSW compost application on tomato crops in Mediterranean conditions: Effects on agronomic performance and nitrogen utilisation. Compost Sci. Util. 13:234-42.

Montemurro F, Fiore A, Campanelli G, Tittarelli F, Ledda L, Canali S, 2013. Organic fertilisation, green manure, and vetch mulch to improve organic zucchini yield and quality. HortSci. 48:1027-33.

Muramoto J, Smith RF, Shennan C, Klonsky KM, Leap J, Silva Ruiz M, Gliessman SR, 2011. Nitrogen contribution of legume/cereal mixed ASCs and organic fertilisers to an organic broccoli crop. HortSci. 46:1154-62.

Page AL, Miller RH, Keeny DR, 1982. Methods of soil analysis, Part II. 2nd ed. American Society of Agronomy, Madison, WI, USA.

Patkowska E, Konopin'ski M, 2013. Harmfulness of soil-borne fungi towards root chicory (Cichorium intybus L. var. sativum Bisch.) cultivated with the use of ASCs. Acta Sci. Pol-Hortoru. 
$12: 3-18$

Perdigão A, Coutinho J, Moreira N, 2012. ASCs as nitrogen source for organic farming in southwest Europe. Acta Hortic. 933:355-61.

Rizk MH, 2012. Effect of some legume ASCs and organic fertiliser on petiole nutrient content, productivity and fruit composition of ‘thompson seedless' grapevines. Acta Hortic. 933:381-7.

Rodríguez JC, Shaw NL, Cantliffe DJ, Karchi Z, 2005. Nitrogen fertilisation scheduling of hidroponically grown 'Galia' muskmelon. Proc. Fla. State Hortic. Soc. 118:106-12.

Sanz-Cobena A, García-Marco S, Quemada M, Gabriel JL, Almendros P, Vallejo A, 2014. Do ASCs enhance N2O, CO2 or $\mathrm{CH} 4$ emissions from soil in Mediterranean arable systems? Sci. Total Environ. 466/467:164-74.

Shipley PR, Meisinger JJ, Decker AM, 1992. Conserving residual corn fertiliser nitrogen with winter ASCs. Agron J. 84:869-76.

Smukler SM, O'Geen AT, Jackson LE, 2012. Assessment of best management practices for nutrient cycling: A case study on an organic farm in a Mediterranean-type climate. J. Soil Water Conserv. 67:16-31.

Soil Survey Staff, 1999. Soil taxonomy. A basic system of soil classification for making and interpreting soil surveys. Agriculture Handbook 436, USDA.-NRCS. Washington, DC, USA.

Song S, Lehne P, Le J, Ge T, Huang D, 2010. Yield, fruit quality and nitrogen uptake of organically and conventionally grown muskmelon with different inputs of nitrogen, phosphorus, and potassium. J. Plant Nutr. 33:130-41

Sullivan P, 1998. Overview of ASCs and green manures,
Fundamentals of sustainable agriculture, Appropriate Technology Transfer for Rural Areas (ATTRA). Available from: http://www.attra.org/attra-pub/covercrop.html\#uses

Teasdale JR, Mirsky SB, Spargo JT, Cavigelli MA, Maul JE, 2012. Reduced-tillage organic corn production in a hairy vetch ASC. Agron. J. 104:621-8.

Teasdale JR, Mohler CL, 1993. Light transmittance, soil temperature, and soil moisture under residue of hairy vetch and rye. Agron. J. 85:673-80.

Thorup-Kristensen K, Dresbøll DB, Kristensen HL, 2012. Crop yield, root growth, and nutrient dynamics in a conventional and three organic cropping systems with different levels of external inputs and $\mathrm{N}$ re-cycling through fertility building crops. Eur. J. Agron. 37:66-82.

UNESCO-FAO, 1963. Bioclimatic map of the Mediterranean zone. UNESCO, Place de Fontanay, Paris; FAO, Rome, NS162/III, 22A, 60 pp.

Walkley A, Black IA, 1934. An examination of the Degtjareff method for determining organic carbon in soils: Effect of variations in digestion conditions and of inorganic soil constituents. Soil Sci. 63:251-63.

Wezel A, Casagrande M, Celette F, Vian JF, Ferrer A, Peigné J, 2014. Agroecological practices for sustainable agriculture. A review. Agron. Sustain. Develop. 34:1-20.

Wortman SE, Francis CA, Bernards ML, Drijber RA, Lindquist JL, 2012. Optimising ASC benefits with diverse mixtures and an alternative termination method. Agron. J. 104:1425-35. 